\title{
SISTEMA DE AVALIAÇÃO DA RELAÇÃO ENTRE OSCILAÇÕES DE VOLUMETRIA DO MEMBRO RESIDUAL E O ENCAIXE DA PRÓTESE DE AMPUTADOS TRANSTIBIAIS
}

\section{Introdução}

Neste trabalho, propõe-se investigar as mudanças de volumetria do coto em relação ao uso da prótese que podem vir a comprometer o conforto e a usabilidade desta. O objetivo é analisar quanto e como a volumetria do membro residual muda com o uso de prótese ao longo de um período de tempo e como essa variação poderia ser medida usando formas não analógicas.

\section{Método}

Pretende-se criar um sistema que possa ser usado para quantificar as mudanças de volumetria do coto protetizado e futuramente usar os dados para propor soluções mais ergonômicas para o encaixe das próteses. Para tal fim será empregado o uso de tecnologias como a Câmera Térmica, a Captura de Movimento e Fotogrametria, que servirão em conjunto como métodos de visualizar, mensurar e quantificar as mudanças que podem vir a ocorrer durante o uso da prótese.

\section{Resultados}

Foram testados as tecnologias de Fotogrametria, Câmera Térmica em conjunto com captura de movimento com seus devidos métodos de coleta de dados. Os resultados foram comparados com medições analógicas para conferir a precisão destes. As abordagens foram confirmadas como tendo um grau de precisão elevado.

\section{Conclusão}

Os métodos de coleta de dados testados foram capazes de produzir resultados confiáveis e replicáveis em um tempo relativamente reduzido. Estes resultados poderão ser utilizados futuramente para auxiliar a produção de próteses mais ergonômicas e potencialmente proporcionar maior conforto para o usuário. Próteses

Palavras Chave: Membro Residual; Fotogrametria; Design de

\section{Introduction}


In this paper, we propose to investigate the changes in stump volume in relation to the use of the prosthesis that may compromise its comfort and usability. The objective is to analyze how much and how the residual limb volume changes with the use of prosthesis over a period of time and how this variation could be measured using nonanalogue forms.

\section{Method}

It is intended to create a system that can be used to quantify the volume changes of the prosthesis stump and in future to use the data to propose more ergonomic solutions for fitting the prostheses. To this end, the use of technologies such as the Thermal Camera, Motion Capture and Photogrammetry will be used, which will serve together as methods to visualize, measure and quantify the changes that may occur during the use of the prosthesis.

\section{Results} ther with motion capture with their proper data collection methods were tested. Results were compared with analog measurements to check their accuracy. The approaches have been confirmed to have a high degree of accuracy.

\section{Conclusion}

The data collection methods tested were able to produce reliable and replicable results in a relatively short time. These results could be used in the future to help produce more ergonomic prostheses and potentially provide greater comfort for the user.

Keywords: Residual Limb; Photogrammetry; Prosthesis Design 